\title{
Infant mortality and mothers' religious involvement in Brazil ${ }^{*}$
}

\author{
Ana Paula de Andrade Verona* \\ Robert Hummer ${ }^{* * *}$ \\ Cláudio Santiago Dias Júnior*** \\ Luciana Conceição de Lima ${ }^{\star \star \star \star \star}$
}

\begin{abstract}
The growth of Protestantism in Brazil has been associated with changes in mortality and health-related outcomes. Recent research has suggested that affiliation with Protestant churches may positively influence their members' well being by: 1) providing moral directives, 2) creating formal or informal sanctions, and 3) promoting social networks and support. This article uses data from the 1996 and 2006 Brazilian Demographic Health Surveys (DHS) and Cox's proportional hazard models to examine the relationship between infant mortality and mothers' religious involvement. Unadjusted results show that differences in the hazard ratios of infant mortality by mothers' religious involvement are considerable and statistically significant. When one controls demographic and socioeconomic variables in the 1996 DHS, the baseline relationship disappears, supporting the hypothesis of selectivity. Results using the 2006 DHS are somewhat different and suggest that the association between religious involvement and infant mortality was stronger in Brazil in 2006 than in 1996. This research should encourage future studies on religious involvement and health-related outcomes in Brazil. This topic deserves further consideration from Brazilian demographers not simply because this country has undergone enormous changes in its religious landscape over recent decades, but also because religion can affect believers' lifestyles and behaviors, and this can indirectly influence their health and well-being.
\end{abstract}

Keywords: Religion. Infant mortality. Cox proportional hazard model. Brazil.

\section{Introduction}

Recent decades have witnessed a rapid and widespread pluralization of Brazil's religious landscape, which is now characterized by an enormous variety of religious beliefs and practices, as well as an uptake in new religious behaviors (PIERUCCI; PRANDI, 2000; DECOL, 1999; CHESNUT, 1997; BURDICK, 1993; BRUNEAU, 1982). Among the changes associated with this process of religious transformation, the growth of

\footnotetext{
${ }^{*}$ A preliminary version of this article was presented at the 2009 meeting of the Population Association of America (PAA) in Detroit, Michigan.

${ }^{* *}$ PhD candidate in the University of Texas at Austin, Department of Sociology, the Population Research Center. She received her masters' degree in Demography at Cedeplar, Federal University of Minas Gerais.

${ }_{* * *}$ Professor in the University of Texas at Austin, Department of Sociology.

**** Professor in the Federal University of Minas Gerais, Department of Nursing.

***** Graduate Student in the Federal University of Minas Gerais, Department of Demography, Cedeplar. She received her masters' degree in Demography at Cedeplar, Federal University of Minas Gerais.
} 
Protestantism has attracted special attention: the Protestant population increased in Brazil from three percent in 1940 to fifteen percent in 2000 (IBGE, 2007; MARIANO, 2004). This growth, however, has not been gradual; it was largely concentrated in the 1990s, a decade that experienced an explosive increase in the number of people converting to Protestantism, led by the Pentecostal Protestant denominations.

The growth of Protestantism in Brazil has been related to changes in behaviors and attitudes that may affect mortality and healthrelated outcomes. Some researchers have suggested, for instance, that Protestantism, and more recently Pentecostal Protestantism, may positively change health-related behaviors such as alcohol consumption, smoking, drug use, violence, and sexual risks (CHESNUT, 2003, 1997; BURDICK, 1993; MARIZ, 1994). These changes often occur among men and can affect gender relations and equity, encouraging, for instance, the responsible fathering of children (WOOD; WILLIAMS; CHIJIWA, 2007). Moreover, Protestants in Brazil very often claim to experience economic improvement after their conversion (MARIZ, 1994). As a result of abstaining from alcohol, for example, they are more able to save money to invest in cash crops, land, housing, and consumer durables (BRUSCO, 1995).

Among other changes, the recent transformation in Brazil's religious landscape has been associated with improvements in child welfare there and in other Latin American countries (VALLE, FERNANDEZ; POTTER, 2009; WOOD; WILLIAMS; CHIJIWA, 2007), including more positive health outcomes and lower risk of death. Trying to better understand this connection, the purpose of this article is to examine the association between mothers' religious involvement (as measured by mothers' religious affiliation and religious service attendance) and infant mortality in Brazil.
Three particular questions guide our research: (1) Are mothers' religious denomination and religious service attendance associated with infant mortality in Brazil? (2) Can these associations be accounted for when one controls for socioeconomic and demographic characteristics that are also related to the risk of infant mortality? (3) Did the association between religious variables and infant mortality change between 1996 and 2006?

\section{The growth of protestantism in Brazil}

The nineteenth century was marked by the arrival of several Protestant missionary churches in Brazil (CHESNUT, 2003, 1997; READ; INESON, 1973), best represented by Lutherans, Presbyterians, Methodists, Baptists, Episcopalians, and Seventhday Adventists. These denominations are referred to as traditional, or mainline, Protestant churches. Although initially they were tiny minorities, they acted as protagonists in remaking the religious landscape in Brazil as well as in all of Latin America (CHESNUT, 2003).

Although traditional Protestants began growing in numbers in Brazil during the nineteenth century, Pentecostal Protestantism is a twentieth-century phenomenon, as it first arrived in Brazil in 1911 (ALVES; NOVELLINO, 2006; MARIANO, 2004; DECOL, 1999). Among other factors, it has been characterized by the workings of the Holy Spirit as manifested in the gifts of healing, prophecy, and the speaking of tongues. Pentecostal Protestants were first represented by the Assemblies of God, and later by other churches, such as the Foursquare Gospel Church (1951), Brazil for Christ (1955), and God Is Love (1962). More recently, during the 1970 s and 1980s, neoPentecostal churches ${ }^{1}$ emerged in Brazil, led by the Universal Church of the Kingdom of God (MARIANO, 2004).

\footnotetext{
1 Unlike their major religious competitors, neo-Pentecostal churches have tended to specialize in exorcism of demons, a specific type of faith healing (CHESNUT, 2003). Neo-Pentecostal churches also differ from traditional Pentecostals through what is known as prosperity theology (MARIANO, 2004), which teaches that material and spiritual blessings are connected. Following this theology, neo-Pentecostal churches provide services that focus on financial prosperity and social mobility.
} 
The recent growth of Pentecostal Protestantism in Brazil has called attention to the social consequences of religious conversion. In order to better understand such changes, it is important to emphasize that the great majority of Pentecostal Protestant converts in Brazil have consisted of poor and very poor people. In his book about the Pentecostal boom in Brazil, Andrew Chesnut (1997) explains that Pentecostal Protestantism enjoyed overwhelming success in appealing to the poor based on the idea of a positive transformation for this group. Believers, for instance, cannot claim to be fully converted until they have completely abandoned practices such as alcohol consumption, gambling, and pre- or extra-marital sex (MARIANO, 2004; BURDICK, 1993).

\section{Explanations for religious influences}

Religious involvement can promote better health outcomes by regulating healthrelated conduct and shaping behavior and lifestyle choices in ways that decrease the risk of disease and mortality. Numerous studies have suggested mechanisms by which religious involvement can improve people's health (PAGE; ELLISON; LEE, 2008; GEORGE; ELLISON; LARSON, 2002; KOENIG; MCCULLOUGH; LARSON, 2000; ELLISON; LEVIN, 1998). According to these studies, religion can influence health and mortality by: 1) providing moral directives, 2) creating formal or informal sanctions on members who deviate from the group's standards, and/or 3) promoting social networks and support (PAGE; ELLISON; LEE, 2008). Not surprisingly, individuals with greater religious commitment or somehow more religiously involved within their community are expected to be more affected by such mechanisms.

Even though there is almost no empirical evidence as to how these mechanisms work in Brazil, Protestant churches in the country may be offering an environment for the emergence of some of the pathways suggested above. As explained earlier, Protestant churches in Brazil strongly disapprove of unhealthy behavior, such as alcohol consumption and drug use, and the avoidance of such practices can improve mothers' health and birth outcomes, and decrease the risk of infant mortality.

Moreover, Pentecostal Protestant churches in Brazil have been very effective restricting extramarital sex and have helped reduced family conflict and disruption (CHESNUT, 2003; BURDICK, 1993). For example, Hill, Cleland and Ali (2004), when examining the association between religious affiliation and extramarital sex among men in Brazil, found that non-evangelical men were significantly more likely to report having had an extramarital partner and/or unprotected extramarital sex than members of evangelical religions.

Protestant congregations also provide moral guidance and practical advice on family life, including marriage, childbearing and child rearing (MARIANO, 2004; BURDICK, 1993). For example, McKinnon, Potter and Garrard-Burnett (2008) recently explored the relationship among Protestantism, fertility and family formation among adolescents aged 15 to 17 living in the Rio de Janeiro Metropolitan Region. The researchers note that the odds of ever having had a live birth is about one-third lower for adolescent women belonging to Baptist, other mainline Protestant, Assembly of God, or other Pentecostal Protestant churches, than for Catholics, adjusted for individual- and community-level controls. They also found that adolescents who belonged to the Assembly of God, other Pentecostal Protestant, or other mainline Protestant churches were much more likely to be married than Catholics.

Protestants in Brazil, therefore, may be more likely to be married and less likely to divorce and have family conflicts than members of other religious groups. Among other factors, this might be positively associated with the amount of resources available in the household, including income level and parental attention, which can reduce risks of infant mortality.

In addition, since Protestant churches strongly discourage certain unhealthy behaviors, they also impose severe sanctions on those members who disobey their doctrine, and this may help inhibit 
such behaviors. In fact, some researchers have emphasized that social sanctions on unhealthy behavior are very strong in closed Protestant communities (BURDICK, 1993; MARIZ, 1994).

Finally, religious involvement may indirectly promote positive child health outcomes by promoting social networks and support. It is well known that Protestants, and more recently, Pentecostal Protestants, in Brazil, encourage self-help networks that are national in scope. They usually offer not only psychological and spiritual support, but also financial assistance, opening their homes to people in need, trying to help others find jobs, or even offering childcare support (WOOD; WILLIAMS; CHIJIWA, 2007; CHESNUT, 1997; MARIZ, 1994). By providing access to these resources, which can be mobilized in times of economic need, sickness, and emergency, religion-based communities can enhance infant and child welfare, especially among the poor.

\section{Alternative explanations}

Although religious involvement may work through all these mechanisms to affect health outcomes and mortality, the influence of religion is often under suspicion. As pointed out by Regnerus (2007), there is a skeptical view suggesting that apparent religious influences may actually be caused by at least two different factors: (1) selection effects, or (2) reverse causation. The first, selection effects, assumes that both the predictor (e.g., religion) and the outcome (e.g., infant mortality) are, in fact, consequences of some other unobservable or unknown factor or factors that may cause both independently (REGNERUS; SMITH, 2005). According to Hummer et al. (2004), the idea behind selectivity is that people who are more religiously involved may differ in key ways from others who are less involved, and such differences may be the real reasons behind an observed relation between religious involvement and mortality risks. Thus, at least demographic and socioeconomic factors should be controlled in order to assess whether the overall association between religious involvement and mortality occurs independently of these variables, works through the mechanisms mentioned above, or is simply spurious.

The second explanation, reverse causation (or religious exit), highlights that the causal direction in question may be inverse, that is, decisions about religion are a product of the outcome under consideration (e.g., infant mortality), and not the other way around. This bias, however, cannot be evaluated using the existing Brazilian data.

\section{Data and method}

The data for this study come from the 1996 and 2006 Brazilian Demographic and Health Surveys (DHS). They are nationally representative surveys of women aged 15-49, and include detailed information on socio-demographic variables and child health. Because both surveys are based on a stratified two-stage cluster design, the sampling weights and primary sampling units (used in clustering) must be specified. In the software Stata version 10 , this is possible using the "svyset" command, which produces estimates of standard errors and statistical tests that take into account the complex design of the survey. All descriptive and statistical analyses shown here are corrected by this command.

The total samples are composed of 12,612 women in 1996 and 15,575 in 2006, 5,045 and 6,054 of whom, respectively, had had at least one child during the five years preceding the survey. This study was restricted to the analysis of these recent births because the quality of information on recent births is better than older information. Previous studies have examined DHS data quality on several demographic measures (MARCKWARDT; RUSTEIN, 1996; RUSTEIN; BICEGO, 1990), including a number of questions about retrospective ages reported at the time of the interviews. One of them concerns children's age at death, which is particularly important for this research. In general, these studies have argued that data quality is better when gathered from younger respondents and when the events occurred within only a few years before the survey (GYIMAH, 2007). Corroborating these 
findings, consistency tests mentioned in the final report (Appendix C) of the 1996 Brazil DHS highlights that information on the age of children who died during the five years preceding the survey is probably unbiased, since it required relatively little memory effort of the interviewees. ${ }^{2}$

We use the 1996 and 2006 Brazil DHS for three main reasons. First, both datasets have information on children's age at death, which is given in months for those who died before the first birthday. Such information allows the use of a more sophisticated statistical method, the Cox Proportional Hazard Model, to better understand the risk of infant mortality. The second reason is the presence of variables on mothers' religious affiliation and service attendance, which are essential in this research. Lastly, the use of these two data sets allows comparisons over time, which is particularly important due the recent transformation of the Brazilian religious landscape.

The dependent variable is the risk of death for infants under one year of age (0-11 months), measured as the duration from birth to age at death or censoring. Although the 1996 Brazil DHS contains information for children born during the five-year period preceding the survey, the question concerning age at death was collected only from those mothers who lost a child by the age of two. From the sample of 5,045 children born between 1991 and 1996, 227 died before turning two years of age (although only 23 died between ages 12 and 24 months). Because roughly $90 \%$ of all information about age at death concerned deaths of children under the age of one year, this study has restricted the analysis to them. That is, as mentioned above, this study will focus on predicting the risk of infant mortality.
Following the same criterion, there were 99 infant deaths in the 2006 DHS.

It is worth mentioning that the majority of those children in the 1996 and 2006 DHS samples were right censored; that is, they survived the first year of life. In order to account for censoring in the estimation of exposure time, an event history model was employed. Thus, we use the Cox proportional hazards model (ALLISON, 2005). This model is a semi-parametric method since it does not require the researcher to choose some particular probability distribution to represent survival times (ALLISON, 2005). It can be written as:

$h_{i}(t)=h_{0}(t) \exp \left(\beta X_{i}\right)$, where $h_{i}(t)$ is the transition rate; $h_{0}(t)$ is the baseline rate, which is the hazard function for an individual with the value zero on all covariates; and $\beta$ is the vector of parameters for the covariates $\left(X_{i}\right)$ in the model.

Since the objective of this study is to examine whether mothers' religious involvement is associated with infant mortality, the main independent variables employed here are the mothers' religious affiliation and religious service attendance. The 1996 Brazil DHS classifies religious affiliation into eight groups3: (1) Roman Catholicism, (2) Protestantism, (3) Evangelicals, (4) Spiritism $^{4}$, (5) Afro-Brazilian religions ${ }^{5}$, (6) Oriental religions, (7) Jewish, and (8) others. The 2006 DHS, on the other hand, classifies religious affiliation into six groups: (1) Roman Catholicism, (2) Traditional Protestantism, (3) Pentecostalism, (4) Spiritism, (5) AfroBrazilian religions, and (6) others. Both data sets also contain a no-religion category. In an attempt to allow comparisons between surveys, the new religious affiliation variable presented here has been classified into three groups: (1) Roman Catholicism

\footnotetext{
2 More information can be found at the following link: <http://www.measuredhs.com/pubs/pub_details.cfm?ID=\%20 119\&SrchTp $=$ advanced $>$.

3 One limitation here is the crude categorization of the measure of religious affiliation. Brazil's religious landscape is characterized by a large number of denominations and one could argue that a broad categorization hides important sub-denominational differences that may impact infant health and mortality. In future surveys, including the DHS, a more nuanced categorization of religious affiliation is needed.

${ }^{4}$ Spiritism, or French spiritualism, is based on books written by the French educator Allan Kardec, in which he reported attempts to communicate with spirits.

${ }^{5}$ In Brazil, Umbanda and Candomblé, are the two principal afro-Brazilian religions. Their main elements are: possession by spirits, animal sacrifice, and syncretism with Catholicism.
} 
(the reference group), (2) Protestantism (including Protestants and Evangelicals in 1996, and traditional Protestants and Pentecostals in 2006), and (3) no religion. Moreover, taken together, less than 5 percent of the women reported belonging to other religious affiliations in 1996 and 2006. Consequently, the number of infant deaths within these groups was extremely low and thus excluded from our analysis.

Information on attendance at religious services was obtained through the following question: "How often do you go to church, temple, or other religious services?" In each survey, women chose one of five options, namely, (1) Once a week, (2) Twice a month, (3) Once a month, (4) Less than once a month, and (5) Never, in 1996, and (1) More than once a week, (2) Weekly, (3) Once to three times a month, (4) Less than monthly, and (5) Never, in 2006. Again, in order to make comparisons between surveys, a new religious service attendance categorization was created containing three groups: (1) weekly or more frequently, (2) less than weekly, and (3) less than monthly or never (the reference group).

Many factors are viewed as confounding or mediating the relationship between mothers' religious involvement and infant mortality. The demographic controls used in this study are mothers' race, parity, geographic region and place of residence. Mothers' race was measured as a whitenonwhite dichotomous variable. Those mothers who identified themselves as white were the reference group. Information on parity was separated into 3 categories: mothers with one child (the reference group), two children, and three or more. Parity may be considered a measure of competition for resources inside the household. Families with three or more children may have more limited financial resources and less time, and provide less attention and supervision for each child compared to small-size families. Geographic region of residence was broken down into five categories, which include: North, Northeast, South, Southeast, and Central-West. The Northeast, the poorest region in Brazil, was demarcated as the reference group. Finally, place of residence is measured as rural and urban areas (the reference category).

The socioeconomic variables included here were mothers' education, marital status, and housing quality. Mothers' education was categorized into two groups: below secondary, and secondary or higher (the reference group). Mothers' education and infant mortality may be related due to, among other factors, the higher income of better-educated women, which would imply access to more appropriate pre-natal care, and better diets. Moreover, education increases knowledge about healthful practices during pregnancy (e.g., hygiene, nutrition) and increases women's ability to access information (LANDALE; OROPESA; GORMAN, 2000). Thus, higher education in mothers is expected to be negatively related to infant mortalityMarital status can also be an important socioeconomic variable. Infants born to unmarried women may be at higher risk of mortality as a consequence of inadequate family resources (EBERSTEIN; NAM; HUMMER, 1990). On the questionnaire, marital status was divided into two categories: married and unmarried (this latter including those who are single, divorced, widowed or cohabiting). The unmarried respondents make up the reference category.

Quality of housing was also used as a control. Here, we classified household water source as tap water (the reference group), and other. This variable is closely correlated to socioeconomic status or standard of living. Infants living in houses with tap water may have lower mortality rates due to better sanitation.

Another variable included in the analysis is the mothers' age at first birth, which was broken down into two categories: under the age of 20 (the reference group), and 20 or over. Teenage childbearing has been recognized in some studies as a social response to socioeconomic disadvantage, which might expose women to environmental factors that elevate infant mortality (GERONIMUS, 1987). Teenage motherhood in Brazil is increasingly concentrated among socioeconomically disadvantaged populations, especially among the least-educated women, those at 
the lowest income levels, and residents of urban areas (BERQUÓ; CAVENAGHI, 2005). In a study regarding the determinants of neonatal and post-neonatal mortality in the City of São Paulo, Machado and Hill (2003) noted that infants of adolescent mothers had substantially higher mortality rates during both the neonatal and post-neonatal periods as compared to infants of mothers between ages 20 and 24. This difference was statistically significant regardless of demographic, socioeconomic, and child health variables.

Finally, it is essential to highlight that one important limitation of this study is the crosssectional nature of the data, which makes it impossible to examine causal relationships between mothers' religious involvement and infant mortality. Thus, instead of suggesting that religion affects child survival, it is reasonable to assume that seeing an infant of one's own die might alter a mother's religious beliefs, affiliation or behavior. Even though this is a limitation to the research, at this point there are no alternative data sets for modeling the association between religious involvement and infant mortality in Brazil.

\section{Results}

Table 1 suggests that mothers in our 1996 DHS sample differ according to religious

TABLE 1

Weighted percentage distribution of variables by mothers' religious affiliation and attendance Brazil - 1996

\begin{tabular}{|c|c|c|c|c|c|c|c|}
\hline \multirow[b]{3}{*}{ Variables } & \multirow{2}{*}{\multicolumn{3}{|c|}{ Religious affiliation }} & \multirow{2}{*}{\multicolumn{3}{|c|}{ Religious attendance }} & rcentage \\
\hline & & & & & & & \multirow[b]{2}{*}{ Total } \\
\hline & Catholicism & Protestantism & $\begin{array}{c}\text { No } \\
\text { religion }\end{array}$ & $\begin{array}{c}\text { Once a } \\
\text { week }\end{array}$ & $\begin{array}{c}\text { Once or twice } \\
\text { a month }\end{array}$ & $\begin{array}{l}\text { Less than once a } \\
\text { month or never }\end{array}$ & \\
\hline \multicolumn{8}{|l|}{ Mother's ethnic group } \\
\hline White & 37 & 39 & 35 & 39 & 39 & 35 & 37 \\
\hline Non-white & 63 & 61 & 65 & 61 & 61 & 65 & 63 \\
\hline \multicolumn{8}{|l|}{ Parity } \\
\hline One & 25 & 21 & 29 & 24 & 25 & 26 & 25 \\
\hline Two & 31 & 32 & 30 & 32 & 33 & 29 & 31 \\
\hline Three or more & 44 & 47 & 41 & 43 & 43 & 45 & 44 \\
\hline \multicolumn{8}{|l|}{ Place of residence * } \\
\hline Urban & 74 & 84 & 73 & 81 & 69 & 74 & 75 \\
\hline Rural & 26 & 16 & 27 & 19 & 31 & 26 & 25 \\
\hline \multicolumn{8}{|l|}{ Region * } \\
\hline South, RJ, SP & 36 & 49 & 41 & 43 & 36 & 40 & 40 \\
\hline Central-west & 14 & 13 & 11 & 18 & 12 & 9 & 12 \\
\hline Northeast & 37 & 21 & 38 & 24 & 40 & 40 & 35 \\
\hline North & 6 & 6 & 4 & 7 & 5 & 5 & 6 \\
\hline Central-east & 7 & 11 & 6 & 8 & 7 & 6 & 7 \\
\hline \multicolumn{8}{|l|}{ Mother's education* } \\
\hline Below Secondary & 52 & 60 & 49 & 60 & 49 & 50 & 53 \\
\hline Secondary or higher & 48 & 40 & 51 & 40 & 51 & 50 & 47 \\
\hline \multicolumn{8}{|l|}{ Marital status* } \\
\hline Married & 60 & 71 & 38 & 68 & 64 & 52 & 60 \\
\hline Unmarried & 40 & 29 & 62 & 32 & 36 & 48 & 40 \\
\hline \multicolumn{8}{|l|}{ Mother's age at first birth* } \\
\hline Under20 & 48 & 43 & 56 & 43 & 49 & 50 & 48 \\
\hline 20 or over & 52 & 57 & 44 & 57 & 51 & 50 & 52 \\
\hline \multicolumn{8}{|l|}{ Dwelling's water source* } \\
\hline Tap & 67 & 75 & 65 & 74 & 63 & 66 & 68 \\
\hline Other & 33 & 25 & 35 & 26 & 37 & 34 & 32 \\
\hline Total & 80 & 14 & 6 & 30 & 23 & 47 & 100 \\
\hline Unweighted sample size & 4,002 & 616 & 309 & 1,383 & 1,219 & 2,341 & 4,936 \\
\hline
\end{tabular}

Source: The 1996 Brazil Demographic Health Survey.

$\chi^{2}$ (Chi-square) test: ${ }^{\star} p<0.05$. 
denominations and attendance at religious services in some of the demographic and socioeconomic factors selected here. For example, $52 \%$ of Catholic mothers had less than secondary education, whereas $60 \%$ of Protestant mothers reported having the same level of education. In terms of marital status, $60 \%$ of Catholic mothers were married compared with $71 \%$ of Protestant mothers. This difference is even higher in relation to religious service attendance: $68 \%$ of mothers who attended religious service weekly were married while this percentage is $52 \%$ for mothers who attended less than monthly or not at all. Moreover, $43 \%$ of the mothers who attended a religious service once a week in 1996 had their first child during adolescence, compared with $50 \%$ of mothers who attended religious services less than once a month or not at all.

Table 2, on the other hand, shows some demographic and socioeconomic differences in terms of religious affiliation and attendance by mothers between the 2006 and the 1996 DHS samples. Such differentials for 2006 seem to be less pronounced than those for 1996. One exception concerns the distribution by marital status: $35 \%$ of Catholic mothers were married in 2006 compared with $54 \%$ of Protestant mothers and with $14 \%$ of mothers with no religious affiliation. Marital status

TABLE 2

Weighted percentage distribution of variables by mothers' religious affiliation and attendance Brazil - 2006

\begin{tabular}{|c|c|c|c|c|c|c|c|}
\hline \multirow[b]{3}{*}{ Variables } & & & & & & Per & centage \\
\hline & \multicolumn{3}{|c|}{ Religious affiliation } & \multicolumn{3}{|c|}{ Religious attendance } & \multirow[b]{2}{*}{ Total } \\
\hline & Catholicism & Protestantism & $\begin{array}{c}\text { No } \\
\text { religion }\end{array}$ & $\begin{array}{c}\text { Once a } \\
\text { week }\end{array}$ & $\begin{array}{c}\text { Once or twice } \\
\text { a month }\end{array}$ & $\begin{array}{l}\text { Less than once a } \\
\text { month or never }\end{array}$ & \\
\hline \multicolumn{8}{|l|}{ Mother's ethnic group } \\
\hline White & 33 & 35 & 31 & 32 & 40 & 32 & 34 \\
\hline Non-white & 67 & 65 & 69 & 68 & 60 & 68 & 66 \\
\hline \multicolumn{8}{|l|}{ Parity } \\
\hline One & 36 & 34 & 45 & 34 & 38 & 39 & 36 \\
\hline Two & 34 & 36 & 28 & 35 & 33 & 33 & 34 \\
\hline Three or more & 30 & 30 & 27 & 31 & 29 & 28 & 30 \\
\hline \multicolumn{8}{|l|}{ Place of residence } \\
\hline Urban & 77 & 79 & 81 & 79 & 79 & 78 & 79 \\
\hline Rural & 23 & 21 & 19 & 21 & 21 & 22 & 21 \\
\hline \multicolumn{8}{|l|}{ Region * } \\
\hline North & 11 & 11 & 10 & 14 & 8 & 9 & 11 \\
\hline Northeast & 33 & 21 & 31 & 24 & 30 & 34 & 30 \\
\hline Southeast & 35 & 49 & 41 & 43 & 38 & 36 & 39 \\
\hline South & 14 & 11 & 10 & 10 & 17 & 13 & 13 \\
\hline Central- west & 7 & 8 & 8 & 9 & 8 & 7 & 7 \\
\hline \multicolumn{8}{|l|}{ Mother's education* } \\
\hline Below Secondary & 60 & 54 & 67 & 56 & 59 & 62 & 59 \\
\hline Secondary or higher & 40 & 46 & 33 & 44 & 41 & 38 & 41 \\
\hline \multicolumn{8}{|l|}{ Marital status* } \\
\hline Married & 35 & 54 & 14 & 52 & 40 & 26 & 38 \\
\hline Unmarried & 65 & 46 & 86 & 48 & 60 & 74 & 62 \\
\hline \multicolumn{8}{|l|}{ Mother's age at first birth* } \\
\hline Under 20 & 50 & 49 & 65 & 48 & 48 & 55 & 49 \\
\hline 20 or over & 50 & 51 & 35 & 52 & 52 & 45 & 51 \\
\hline \multicolumn{8}{|l|}{ Dwelling water source } \\
\hline Tap & 62 & 65 & 69 & 64 & 61 & 63 & 63 \\
\hline Other & 38 & 35 & 31 & 36 & 39 & 37 & 37 \\
\hline Total & 63 & 27 & 10 & 38 & 19 & 43 & 100 \\
\hline Unweighted sample size & 3,966 & 1,367 & 524 & 2,265 & 1,123 & 2,453 & 5,841 \\
\hline
\end{tabular}

Source: The 2006 Brazil Demographic Health Survey.

$\chi^{2}$ (Chi-square) test: ${ }^{*} p<0.05$. 
differentials were also high as per religious service attendance in 2006.

Table 3 shows, for both 1996 and 2006, the number of infant deaths per 1000 births for each variable selected here, as well as the unadjusted effects of the independent variables on infant mortality. These results include differences in mothers' religious affiliation and attendance in relation to infant mortality at the bivariate level. In 1996, infants of Protestant mothers seem to have been at lower risk of dying than newborns of Catholic mothers. The number of infant deaths per 1,000 births and the unadjusted risk ratio among Protestants are lower than among Catholics. Significant differences are also

TABLE 3

Deaths per 1000 births and unadjusted infant mortality hazard ratios Brazil -1991/1996-2001/2006

\begin{tabular}{|c|c|c|c|c|}
\hline \multirow[b]{2}{*}{ Variables } & \multicolumn{2}{|r|}{1996} & \multicolumn{2}{|c|}{2006} \\
\hline & $\begin{array}{l}\text { Deaths per } \\
1000 \text { births }\end{array}$ & $\begin{array}{l}\text { Unadjusted hazard } \\
\text { ratios (exp b) }\end{array}$ & $\begin{array}{l}\text { Deaths per } \\
1000 \text { births }\end{array}$ & $\begin{array}{l}\text { Unadjusted hazard } \\
\text { ratios (exp b) }\end{array}$ \\
\hline \multicolumn{5}{|l|}{ Religious affiliation } \\
\hline Catholicism & 42 & 1.00 & 17 & 1.00 \\
\hline Protestantism & 28 & $0.66^{*}$ & 13 & 0.77 \\
\hline No religion & 59 & $1.41^{*}$ & 19 & 1.11 \\
\hline \multicolumn{5}{|l|}{ Religion attendance } \\
\hline Less than once a month or never & 45 & 1.00 & 21 & 1.00 \\
\hline Once or twice a month & 50 & 1.12 & 14 & 0.64 \\
\hline Once a week & 28 & $0.62^{* *}$ & 13 & $0.64 * *$ \\
\hline \multicolumn{5}{|l|}{ Demographic variables } \\
\hline \multicolumn{5}{|l|}{ Mother's ethnic group } \\
\hline White & 24 & 1.00 & 6 & 1.00 \\
\hline Non-white & 50 & $2.08^{* * *}$ & 36 & $2.35^{\star *}$ \\
\hline \multicolumn{5}{|l|}{ Parity } \\
\hline One & 15 & 1.00 & 10 & 1.00 \\
\hline Two & 34 & $2.26^{\star \star \star}$ & 11 & 1.13 \\
\hline Three or more & 59 & $3.94^{\star * *}$ & 26 & $2.50 * * *$ \\
\hline \multicolumn{5}{|l|}{ Place of residence } \\
\hline Urban & 32 & 1.00 & 17 & 1.00 \\
\hline Rural & 67 & $2.12^{\star \star *}$ & 15 & 0.88 \\
\hline \multicolumn{5}{|l|}{ Region } \\
\hline Northeast & 56 & 1.00 & 22 & 1.00 \\
\hline North & 31 & $0.55^{\star *}$ & 22 & 1.55 \\
\hline Southeast & 25 & $0.44^{\star *}$ & 9 & $0.32^{\star *}$ \\
\hline South & 31 & $0.54^{\star *}$ & 11 & 0.68 \\
\hline Central-west & 35 & $0.62^{*}$ & 17 & 0.90 \\
\hline \multicolumn{5}{|l|}{ Socioeconomic variables } \\
\hline \multicolumn{5}{|l|}{ Mother's education } \\
\hline Below secondary & 54 & $1.93^{\star \star *}$ & 19 & 1.67 \\
\hline Secondary or higher & 28 & 1.00 & 11 & 1.00 \\
\hline \multicolumn{5}{|l|}{ Marital status } \\
\hline Married & 31 & $0.57^{\star \star *}$ & 13 & $0.51^{* *}$ \\
\hline Unmarried & 55 & 1.00 & 19 & 1.00 \\
\hline \multicolumn{5}{|l|}{ Mother's age at first birth } \\
\hline Younger than 20 & 54 & 1.00 & 20 & 1.00 \\
\hline 20 or over & 28 & $0.51^{\star \star *}$ & 12 & 0.83 \\
\hline \multicolumn{5}{|l|}{ Dwelling water source } \\
\hline Tap & 29 & 1.00 & 17 & 1.00 \\
\hline Other & 62 & $2.14^{\star \star *}$ & 15 & 1.34 \\
\hline Unweighted Sample Size & 4,936 & & 5,841 & \\
\hline
\end{tabular}

Source: 1996 and 2006 Brazil Demographic Health Surveys.

* $p<0.1 * * p<0.05 * * * p<0.01$.

Note: Based on births that occurred within 5 years before the survey. 
observed in religious service attendance for both years: whereas there were 28 deaths per 1,000 births among mothers who attended services weekly in 1996, this rate was 45 for those who attended less than once a month or never. In 2006, the number of infant deaths per 1000 births was 13 and 21, respectively, for these same religious groups. The unadjusted effects of mothers' religious attendance suggest that the risk of death was about 38\% lower (p. < 0.05) in 1996, and $36 \%$ lower (p. < 0.05) in 2006, among infants of mothers who attended religious services weekly than among mothers who attended less than monthly or not at all.

With regard to results from the 1996 DHS, the unadjusted effects of mothers' race, parity, place of residence, and region show that the hazard ratios of infant mortality for children born to nonwhite mothers, to those who have more than one child, who live in rural areas or in the Northeast are higher than those of their counterparts. Moreover, infants born to better-educated and married women show lower risks of mortality than those whose mothers have low education and are unmarried. The unadjusted effects of mothers' ages at first birth show that newborns of mothers who had their first child at age $\mathbf{2 0}$ or older are characterized by lower risk of infant mortality. Table 3 also shows that lower hazard ratios were seen among children whose mothers live in dwellings with tap water in 1996. On the other hand, results for the 2006 DHS on Table 3 indicate that only the unadjusted effects of mothers' race, parity, region, and marital status (in addition to high religious attendance) on infant mortality were still strong and statistically significant ten years later.

Table 4 presents multivariate analyses referring to hazard ratios of infant mortality when one controls mothers' religious characteristics and the selected variables in the DHS for 1996 and 2006, respectively. Model 1 of Table 4, which employs data from the $1996 \mathrm{DHS}$, shows that newborns of Protestant mothers lose their statistically significant advantage in terms of infant mortality, compared to Catholic mothers, when mothers' demographic and socioeconomic factors are controlled. Likewise, children of mothers who attend religious services more frequently were no longer less likely than their counterparts to die before turning one year of age.

These results suggest that denominational and religious service attendance differences in infant mortality in Brazil in 1996 were mainly artifacts of the variation in demographic and socioeconomic factors rather than religious factors, per se, and this supports the hypothesis of selectivity. In other words, key variables may be the real reasons behind an apparent association between religion and infant mortality risk. Nevertheless, Model 1 also shows that some demographic and socioeconomic variables, such as marital status and mother's age at first child, show predictable correlations with infant mortality. The adjusted effects of these variables indicate that newborns of married mothers and of mothers who had their first child at age 20 or older are at a lower risk of dying.

Model 2 of Table 4 presents multivariate results using data from the 2006 DHS. Unlike Model 1, Model 2 shows that even when one controls for demographic and socioeconomic variables, a higher level of mothers' religious service attendance remains associated with a lower risk of infant mortality (p. <0.1). This result may suggest that religious participation was a stronger predictor of infant mortality in Brazil in 2006 than in 1996. On the other hand, the effects of some demographic variables, such as marital status and age at first child appear to be weaker in 2006 than in 1996.

\section{Discussion}

The existing literature describes a large set of demographic, socioeconomic, and health variables, as well as birth outcomes, most likely to affect infant survival in Brazil (MACHADO; HILL, 2003; RUTSTEIN, 2000). Nevertheless, almost no attention has been given to religious involvement.

In fact, virtually nothing is known about the implications of religious participation for infant or child mortality in Brazil. Wood, Williams, and Chijiwa (2007) conducted one of the few studies that have contributed to this topic. The authors analyzed the 
TABLE 4

Multivariate analyses including hazard ratios of infant mortality as per mothers' religious characteristics and other selected variables Brazil - 1991/1996-2001/2006

\begin{tabular}{|c|c|c|}
\hline Variables & Model 1 - 1996 & Model 2-2006 \\
\hline \multicolumn{3}{|l|}{ Religious affiliation } \\
\hline Catholicism & 1.00 & 1.00 \\
\hline Protestantism & 0.99 & 0.88 \\
\hline No religion & 1.28 & 0.91 \\
\hline \multicolumn{3}{|l|}{ Religion attendance } \\
\hline Less than once a month or never & 1.00 & 1.00 \\
\hline Once or twice a month & 1.30 & 0.64 \\
\hline Once a week & 0.91 & $0.63^{*}$ \\
\hline \multicolumn{3}{|l|}{ Demographic variables } \\
\hline \multicolumn{3}{|l|}{ Mother's ethnic group } \\
\hline White & 1.00 & 1.00 \\
\hline Non-white & $1.49^{* *}$ & 1.19 \\
\hline \multicolumn{3}{|l|}{ Parity } \\
\hline One & 1.00 & 1.00 \\
\hline Two & $2.29^{\star \star}$ & 1.00 \\
\hline Three or more & $3.58^{\star \star \star}$ & $2.35^{\star \star}$ \\
\hline \multicolumn{3}{|l|}{ Place of residence } \\
\hline Urban & 1.00 & 1.00 \\
\hline Rural & 1.09 & 0.90 \\
\hline \multicolumn{3}{|l|}{ Regions } \\
\hline Northeast & 1.00 & 1.00 \\
\hline North & $0.64^{\star}$ & 1.00 \\
\hline Southeast & 0.73 & $0.44^{\star \star}$ \\
\hline South & 0.96 & 0.61 \\
\hline Central-west & 1.03 & 0.77 \\
\hline \multicolumn{3}{|l|}{ Socioeconomic variables } \\
\hline \multicolumn{3}{|l|}{ Mother's education } \\
\hline Below secondary & 1.01 & 1.15 \\
\hline Secondary or higher & 1.00 & 1.00 \\
\hline \multicolumn{3}{|l|}{ Marital status } \\
\hline Married & $0.68^{\star \star}$ & 0.88 \\
\hline Unmarried & 1.00 & 1.00 \\
\hline \multicolumn{3}{|l|}{ Mother's age at first birth } \\
\hline Younger than 20 & 1.00 & 1.00 \\
\hline 20 or over & $0.64^{\star \star}$ & 0.89 \\
\hline \multicolumn{3}{|l|}{ Dwelling water source } \\
\hline Tap & 1.00 & 1.00 \\
\hline Other & $1.58^{\star \star}$ & 1.23 \\
\hline - 2 Log likelihood & 3294,4 & 1552,4 \\
\hline
\end{tabular}

Source: The 1996 and 2006 Brazil Demographic Health Surveys.

* $p<0.1 * * p<0.05 * * * p<0.01$.

Note: Based on births that occurred within 5 years before the survey.

association between Protestantism and child mortality in northeastern Brazil in 2000. They were particularly interested in testing the hypothesis that the welfare of children (measured as child mortality) is associated with mothers' religious affiliation. Using data from the 2000 Brazilian census, the authors found that children born to Protestant mothers in northeastern Brazil are significantly more likely to survive childhood compared to those born to Catholic mothers. This finding is compelling enough to encourage further research, given the recent significant growth of Protestantism in Brazil and other Latin American countries (CHESNUT, 2003, 1997). Furthermore, Wood, Williams, and Chijiwa (2007) separated Protestants into traditional and Pentecostal subgroups, and showed that the traditional subgroups have lower mortality rates than Pentecostal Protestants. 
Results for Rio de Janeiro, however, were somewhat different. Iyer and Monteiro (2004) analyzed the risk of child and adolescent mortality among vulnerable populations in Rio de Janeiro, and found that child mortality rates did not vary by religious affiliation after socioeconomic variables were controlled.

Using data from the 1996 and the 2006 Brazilian Demographic and Health Surveys, this article examined whether there are religious differences (measured by both religious affiliation and service attendance) in infant mortality. This article also assessed whether such differences can be explained by the mothers' demographic and socioeconomic characteristics, and whether the differences changed over this ten-year period. The motivation behind this present study derives from recent transformations in Brazil's religious landscape, which has been marked by the significant growth of Protestantism, which reached surprising numbers in the 1990s (MARIANO, 2004).

At the bivariate level, there was some evidence of significant religious differences in infant mortality in 1996. Newborns of Protestant mothers were found to have a significantly (p. <0.1) lower risk of mortality than infants born to Catholics. This finding may support the results found by Wood, Williams, and Chijiwa (2007) and indicates that some restrictions on members' lifestyles demanded by Protestant churches may be positively affecting mothers' and children' health. In addition, infants of mothers who attended religious services weekly were significantly (p. <0.05) less likely to die before turning one year than their counterparts whose mothers attended less than monthly or did not attend, both in 1996 and 2006.

In the multivariate analyses for 1996 , differences in religious affiliation and service attendance on infant mortality disappeared, which is consistent with the hypothesis of selectivity. Those factors, therefore, are either confounding or mediating the association between mothers' religious identity and infant mortality. Our multivariate results show that infants of married mothers were statistically less likely to die than those of unmarried mothers in 1996. Protestant doctrine in Brazil strongly emphasizes certain forms of social organization, such as the institution of marriage (BURDICK, 1993). Because marriage is so important for Protestant denominations, they have emphasized values favoring it, which can indirectly affect infant mortality.

Likewise, the multivariate models indicate that infants of mothers who had their first child when they were under age 20 were at a higher risk of dying than their counterparts. Protestant churches may therefore indirectly affect infant mortality in Brazil if they discourage adolescent fertility. As explained earlier in this article, the study of McKinnon, Potter and Garrard-Burnett (2008) provides empirical evidence for such an association.

Overall, our main findings from the 1996 DHS indicate that mothers' religious affiliation and service attendance do not have an independent association with infant mortality. However, this non-significant association with religion after controlling for demographic and socioeconomic factors may suggest that the connection is indirect and operates through mediating variables, such as marital status and mothers' age at first child. These associations should be explored with more developed data concerning pregnancy and infant health processes.

Results using the 2006 DHS were somewhat different. Differences in religious service attendance on infant mortality did not completely disappear in our multivariate model, suggesting that religious involvement may have had a stronger correlation with infant mortality in Brazil in 2006 than it did in 1996. One explanation for this influence may be related to the fact that some churches in Brazil strongly disapprove of certain unhealthful behaviors, such as alcohol consumption and drug use, and this stance can improve the mothers' health and reduce the risks of infant mortality. In addition, this same association may be indicating an indirect influence of religion through, for instance, the promotion of social networks and support. It is a well-known fact that some churches in Brazil encourage self-help networks. They usually offer not only spiritual 
support, but also financial assistance, which can be mobilized in times of economic need and sickness. It is expected that those believers who are more religiously engaged and go to church more often may also be more likely to receive such network resources. Again, these associations should be explored with more developed data concerning the believers' experiences in receiving religious services that may help identify the different sorts of collaboration and networks that exist in the churches.

Finally, this research should encourage future studies on religion or religious involvement and health-related outcomes in Brazil. This topic deserves further

\section{References}

ALLISON, P. D. Survival analysis using SAS - A practical guide. Cary, NC: SAS. 2005.

ALVES, J. E. D.; NOVELLINO, M. S. A dinâmica das filiações religiosas no Rio de Janeiro: 1991-2000 - um recorte por educação, cor, geração e gênero. In: PATARRA, N.; AJARA, C.; SOUTO, J. O Rio de Janeiro continua sendo... Rio de Janeiro: Ence/IBGE, 2006, p.275-308.

BERQUÓ, E. S.; CAVENAGHI, S. M. Increasing adolescent and youth fertility in Brazil: a new trend or a one-time event? Paper presented at the Annual Meeting of the Population Association of America, Philadelphia, Pennsylvania, March 30 to April 2, 2005.

BRUSCO, E. E. The reformation of machismo: evangelical conversion and gender in Guatemala. Austin, TX: University of Texas Press, 1995.

BRUNEAU, T. C. The church in Brazil - the politics of religion. Austin, TX: University of Texas Press, 1982.

BURDICK, J. Looking for god in Brazil. Berkeley: University of California Press, 1993.

CHESNUT, R. A. Born again in Brazil the Pentecostal boom and the pathogens of poverty. New Brunswick, NJ: Rutgers University Press, 1997. consideration from Brazilian demographers not simply because this country has experienced remarkable changes in its religious landscape over recent decades, but also because religion can affect believers' lifestyles and behaviors, which may in turn also influence their well-being and health. Research on the association between religion and infant mortality, as well as with other elements of public health in Brazil, such as youth and adult mortality, functional capacity of the elderly, mental and physical diseases, abortion, and violence, are only a few examples of how the study of religion can contribute to a better understanding of demographic phenomena in this country.

CHESNUT, R.A. Competitive spirits - Latin America's new religious economy. New York: Oxford University Press, 2003.

DHS (1996) - Demographic and Health Survey (Banco de Dados). BEMFAM and Macro International, Inc. 1997. Brasil: Pesquisa Nacional sobre Demografia e Saúde, 1996. Calverton, Maryland, USA: BEMFAM and Macro International, Inc. Available in: <http:// www.measuredhs.com/accesssurveys/> Access in: 30 de julho de 2008.

DHS (2006) - Demographic and Health Survey (Banco de Dados). In: Pesquisa Nacional de Demografia e Saúde, 2006. Available in: <http://bvsms.saude.gov.br/ bvs/pnds/> . Access in: 30 de julho de 2008.

DECOL, R. D. Mudança religiosa no Brasil: uma visão demográfica. Revista Brasileira de Estudos de População, 16 (1/2): 121$137,1999$.

EBERSTEIN, I. W.; NAM, C. B; HUMMER. R. A. Infant mortality by cause of death: main and interaction effects. Demography, 27: 413-430, 1990.

ELLISON C. G.; LEVIN. J. S. The religionhealth connection: evidence, theory, and future directions. Health Education Behavior, 25: 700-720, 1998.

FERNANDES, R. C.; SANCHIS, P.; VELHO, O. G.; CARNEIRO, L. P.; MARIZ, C.; MAFRA, 
C. Novo nascimento - Os evangélicos em casa, na igreja e na política. Rio de Janeiro: Mauad, 1998.

GEORGE L. K.; ELLISON, C. G.; LARSON, D. B. Explaining the relationships between religious involvement and health. Psychological Inquiry, 13(3): 190-200, 2002.

GERONIMUS, A. T. On teenage childbearing and neonatal mortality in the United States. Population and Development Review, 13: 245-280, 1987.

GYIMAH, S. O. What has faith got to do with it? Religion and child survival in Ghana. Journal of Biosocial Science, 39: 923937, 2007.

HILL, Z.; CLELAND, J.; ALI, M. Religious affiliation and extramarital sex among men in Brazil. International Family Planning Perspectives, 30(1): 20-26, 2004.

HUMMER, R. A.; ELLISON, C. G.; ROGERS, R. G.; MOULTON, B. E.; ROMERO, R. R. Religious involvement and adult mortality in the United States: renew and perspectives. Southern Medical Journal, 97(12): 12231230, 2004.

KOENIG, H. G.; McCULLOUGH, M. E.; LARSON, D. B. Handbook of religion and health. Oxford: Oxford University Press, 2001.

IBGE - Instituto Brasileiro de Geografia e Estatística. Religião. Uma análise da população com base nos resultados dos Censos Demográficos 1940 e 2000. Rio de Janeiro: IBGE, 2007.

IYER S.; MONTEIRO, M. The risk of child and adolescent mortality among vulnerable populations in Rio de Janeiro, Brazil. Journal of Biosocial Science, 36: 523-546, 2004.

LANDALE, N. S.; OROPESA, R. S.; GORMAN, B. K. Migration and infant death: assimilation or selective migration among Puerto Ricans? American Sociological Review, 65(6): 888909, 2000

MACHADO, C. J.; HILL, K. Determinants of neonatal and post-neonatal mortality in the City of São Paulo. Revista Brasileira de Epidemiologia, 6(4): 345-358, 2003.
MARCKWARDT, A. M.; RUTSTEIN, S. O. Accuracy of DHS-II demographic data: gains and losses in comparison with earlier surveys (DHS working papers, n. 19). Calverton, MD: Macro International, 1996.

MARIANO, R. Expansão pentecostal no Brasil: o caso da Igreja Universal. Estudos Avançados, 18(52): 121-138, 2004.

MARIZ, C. Coping with poverty: Pentecostal and Christian Base Communities in Brazil. Philadelphia, PA: Temple University Press, 1994.

MCKINNON, S.; POTTER, J.; GARRARDBURNETT, V. Adolescent fertility and religion in Rio de Janeiro, Brazil in the year 2000: the role of Protestantism. Population Studies, 62(3): 289-303. 2008.

PAGE R. L.; ELLISON, C. G.; LEE, J. Does religiosity affect health risk behaviors in pregnant and postpartum women? Maternal Child Health Journal, Sep. 13(5): 621-632, 2008.

PIERUCCI, A. F. O.; PRANDI, R. Religious diversity in Brazil: numbers and perspectives in a sociological evaluation. International Sociology, 15: 629-639, 2000.

READ, W. R.; INESON, F. A. Brazil 1980: the protestant handbook. Monrovia, CA: Marc, 1973.

REGNERUS, M. D. Forbidden fruit - Sex and religion in the lives of American teenagers. New York: Oxford University Press, 2007.

REGNERUS, M. D.; SMITH, C. Selection effects in studies of religion influence. Review of Religious Research, 47(1): 23-50, 2005.

RUTSTEIN, S. O. Factors associated with trends in infant and child mortality in developing countries during the 1900s. Bulletin World Health Organization, 78: 1256-70, 2000.

RUTSTEIN, S. O.; BICEGO, G. T. Assessment of the quality of data used to ascertain eligibility and age in the Demographic and Health Surveys. An assessment of DHS-I data quality (DHS Methodological Reports, n. 1). Columbia, MD. Institute for Resource Development/ Macro Systems, 1990. 
VALLE, E. D. V.; FERNANDEZ, L.; POTTER, J. Religious affiliation, ethnicity and child mortality in Chiapas, Mexico. Journal for the Scientific Study of Religion, 48(3): 588-603, 2009.
WOOD, C.; WILLIAMS, P.; CHIJIWA, K. Protestantism and child mortality in Northeast Brazil, 2000. Journal for the Scientific Study of Religion, 46(3): 405-416, 2007.

\section{Resumo}

\section{Mortalidade infantil e envolvimento religioso materno no Brasil}

O crescimento do Protestantismo no Brasil tem sido associado a mudanças em variáveis de mortalidade e saúde. Estudos recentes sugerem que a afiliação com igrejas Protestantes pode positivamente influenciar o bem-estar de seus membros a partir: 1) do ensinamento de diretrizes morais; 2) da criação de sanções formais e informais; e 3) da promoção de redes sociais e de suporte. Este trabalho utiliza dados da Pesquisa Nacional de Demografia e Saúde (PNDS) de 1996 e 2006 e modelos de risco proporcional de Cox para examinar a associação entre mortalidade infantil e envolvimento religioso da mãe. Resultados bivariados mostram que as diferenças nas razões de risco da mortalidade infantil por envolvimento religioso materno são consideráveis e estatisticamente significativas. Ao controlar por variáveis demográficas e socioeconômicas na amostra de 1996, esta associação inicial desaparece, o que corrobora a hipótese de seletividade. Resultados usando a PNDS de 2006 mostram, no entanto, que os diferenciais na mortalidade infantil por participação em cultos religiosos ou missas ainda são observados no modelo multivariado. Tal constatação sugere que a associação entre envolvimento religioso materno e mortalidade infantil no Brasil é mais forte em 2006 do que era em 1996. Este trabalho deve encorajar novos estudos sobre a relação entre religião e variáveis de saúde no Brasil. Este tema merece maior consideração dos demógrafos no Brasil não somente porque este país tem passado por profundas mudanças religiosas, mas também porque a religião pode afetar o comportamento e o estilo de vida de seus fiéis, o que, por sua vez, pode influenciar o bem-estar e a saúde destes indivíduos.

Palavras-chave: Religião. Mortalidade infantil. Modelo de risco proporcional de Cox. Brasil.

\section{Resumen}

\section{Mortalidad infantil e implicación religiosa materna en Brasil}

El crecimiento del protestantismo en Brasil ha sido asociado a cambios en variables de mortalidad y salud. Estudios recientes sugieren que la afiliación a iglesias protestantes puede influenciar positivamente en el bienestar de sus miembros por: 1) la enseñanza de directrices morales; 2) la creación de sanciones formales e informales; y 3) la promoción de redes sociales y de apoyo. Este trabajo utiliza datos de la Investigación Nacional de Demografía y Salud (PNDS) de 1996 y 2006 y modelos de riesgo proporcional de Cox para examinar la asociación entre mortalidad infantil e implicación religiosa de la madre. Resultados bivariados muestran que las diferencias en las razones de riesgo de la mortalidad infantil por implicación religiosa materna son considerables y estadísticamente significativas. Al controlar por variables demográficas y socioeconómicas en la muestra de 1996, esta asociación inicial desaparece, lo que corrobora la hipótesis de selectividad. Resultados usando la PNDS de 2006 muestran, no obstante, que los diferenciales en la mortalidad infantil por participación en cultos religiosos o misas se observan incluso en el modelo multivariado. Tal constatación sugiere que la asociación entre implicación religiosa materna y mortalidad infantil en Brasil es más fuerte en 2006 de lo que era en 1996. Este trabajo debe animar nuevos estudios sobre la relación entre religión y variables de salud en Brasil. Este tema merece mayor consideración de los demógrafos en Brasil, no 
solamente porque este país ha pasado por profundos cambios religiosos, sino también porque la religión puede afectar el comportamiento y el estilo de vida de sus fieles, lo que a su vez, puede influenciar en el bienestar y la salud de estos individuos.

Palabras-clave: Religión. Mortalidad infantil. Modelo de riesgo proporcional de Cox. Brasil.

Recebido para publicação em 17/12/2009

Aceito para publicação em 22/04/2010 